\title{
An Analysis Of Perceptions Regarding Knowledge-Worker Instructional Needs In Graduate Management Programs
}

\author{
Robert E. Scully, (Email: rscully@mail.barry.edu), Barry University \\ John W. Russette, (Email: russett@nova.edu), Barry University \\ Robert Preziosi, (Email: preziosi@huizenga.nova.edu), Nova Southeastern University \\ Francisco de Cossio, (Email: dr_decossio@yahoo.com), American Intercontinental University
}

\begin{abstract}
Relevance in Management programs has become a major issue for colleges and universities. The literature posits that proactive educational institutions need to retool and refocus their programs to be consistent with business organizations which have been transformed by technology and global commerce. This study addresses the reliability of contemporary perceptions and postulates expressed in the literature related to effectively managing knowledge-work professionals. A literature search of knowledge-worker writings was collected and perceptions were extracted for further evaluation. These extracted attributes were set into a thirty-five item questionnaire and administered to three demographic groups including: (a) knowledge-workers, (b) knowledgeworker managers, and (c) knowledge worker educators. Results indicate that if such a validated perception-based program were offered it would raise fulfillment of needs for knowledge-workers, managers, and educators and offer a unique, identifiable program related to teaching and researching related to this new management paradigm.
\end{abstract}

\section{INTRODUCTION}

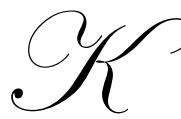

nowledge work is gradually displacing production type work in technologically advanced countries. According to The Economist (November 2001), the fastest growing work force group is knowledge workers, persons whose jobs require advanced and formal education. Current estimates are that this rapidly growing worker segment already comprises two-fifths of the United States workforce, knowledge workers now outnumbering industrial workers by three to one (US Census Bureau, 2000). In his 1999 Management Challenges for the $21^{\text {st }}$ Century, Peter Drucker addresses the issues facing modern organizations with respect to knowledge workers, chronicling the shift to knowledge work in The Age of Discontinuity (1969). Drucker contends that knowledge worker productivity is likely to be the central issue for $21^{\text {st }}$ century organizations, just as productivity of the manual worker was the focus of management one hundred years ago. In fact, he suggests that management theory and practice may move from managing the work of people to managing for performance, i.e., the goal of exploiting specific strengths and knowledge of each individual to enhance organization productivity.

Technological advancement has given support to a shift from the industrial era to the knowledge era, thereby demanding new job and skill set didactics. Work in technologically advanced countries increasingly requires competency in higher-order cognitive skills such as critical thinking and problem solving. At the same time, traditional relationships between managers and workers are also changing. Employees are expected to expand the scope of their individual job, work in teams, and generally become more self-managed, thereby creating an environment where they are more autonomous and empowered (Townsend, DeMarie \& Hendrickson, 1998).

Core issues for modern knowledge worker organizations are workplace competencies, lower level access to knowledge, knowledge database organization, and how opportunities to learn are realized. Directing attention to the dynamics of the learning process - both within business schools and within the business world - provides new possibilities to understand the nature of knowledge and the way it can be acquired. Business leaders seek management tools that both emphasize and resolve problems hindering knowledge sharing. Consequently, educators need to 
understand what competencies and processes are crucial for business schools to prepare graduates for the modern knowledge-based organization (Austin, 1999).

\section{LITERATURE REVIEW}

A 1999 demographic study (Burke, Macdermid ,1999) reflects a shift in the demographic profile of the returning graduate business student. The Canadian work place of the future, it is postulated, will be populated by mature, business experienced, immigrant based and predominantly female students seeking training from business schools across Canada. The Management Education Task Force for the Association to Advance Collegiate Schools of Business (AACSB, 2002), one of the highest standards of achievement for business schools worldwide, questioned the relevance of business school curricula in today's global marketplace. AACSB recommends teaching advanced communications, interpersonal and multicultural skills, negotiations, managing change, and preparing students for global responsibility.

Mintzberg (2003), Doria, Rozanski and Cohen (2003) and others have concluded that business schools have not changed enough to address critical curriculum weaknesses in such areas as communications, relationship management, leadership, and problem solving. Moreover, even when course offerings in nontraditional areas are added, it does not necessarily lead to changes in the all-important core course work, or in the ways in which students are taught. According to Greiner, Bhambri and Cummings (2003), the neglect of behavioral and implementation training results in students graduating with strong conceptual expertise but weak in skills applying that expertise to achieve positive results. Analytical expertise without the complementary behavioral skills to involve others in the total process can result in both badly formulated strategies and failed implementations.

Organizations generally define knowledge as the accumulation of information and the mental structures used to organize that information. It directly influences a leader's capacity to define complex organizational problems and attempt to solve them. The knowledge and expertise of individuals make it possible to think critically about complex issues and identify possible strategies for appropriate change. A knowledgeable leader has many mental structures with which to organize the facts of organizational life. Ryes, Trank, Lawson and Ilies (2003) report that although the organizational world has changed in ways that make behavioral knowledge and skills increasingly important, companies still find they must provide "remedial" behavioral education to their new employees to close certain knowledge gaps not filled by the educational institution.

Revisiting the role of teacher is necessary to get a better understanding of how specialized knowledge and management of this knowledge can create a sustainable competitive advantage for business. The importance of studying the role of knowledge within companies derives from a growing awareness that the capture and spread of knowledge within companies provides a significant explanation for marked differences in productivity and profitability between companies. Business leaders require management tools that emphasize knowledge sharing and resolve problems hindering knowledge sharing.

Schools of management need insight into knowledge required for business practice and how to best prepare students for the workplace. The primary goal of this developmental process paper is to solve the stated research problems by stimulating adaptation of management practices amongst practitioners and policy makers through a new educational product specifically tailored to the knowledge worker environment (Gibney, 2000: Varcoe, 2001).

\section{RESEARCH DESIGN}

The research design, termed Curriculum Development Methodology Cycle (CDMC, Figure 1), employs a three-fold subset of interim processes (Tas, Okeiti, Finley, Postel 1994). The interim processes of the research include: (a) Identifying relevant current postulates, opinions and positions expressed in the current literature regarding knowledge-worker (KW) organizations, (b) Identifying literature defined knowledge-worker competencies, and (c) Identifying current curricula delivery systems, as expressed in the literature, for knowledge-worker training. The research design goal will ultimately be used to develop a KW specific learning model, highly correlated to the literature that reflects the highest ranking across the three sample groups canvassed. The CDMC pictorially highlights the research components that support and develop the learning expectations and course outcomes for the resulting $\mathrm{KW}$ 
model. According to Vance (2001), the application of this developmental methodology is appropriate to develop and validate a KW specific course of study and evaluate the existing educational $\mathrm{KW}$ product line.

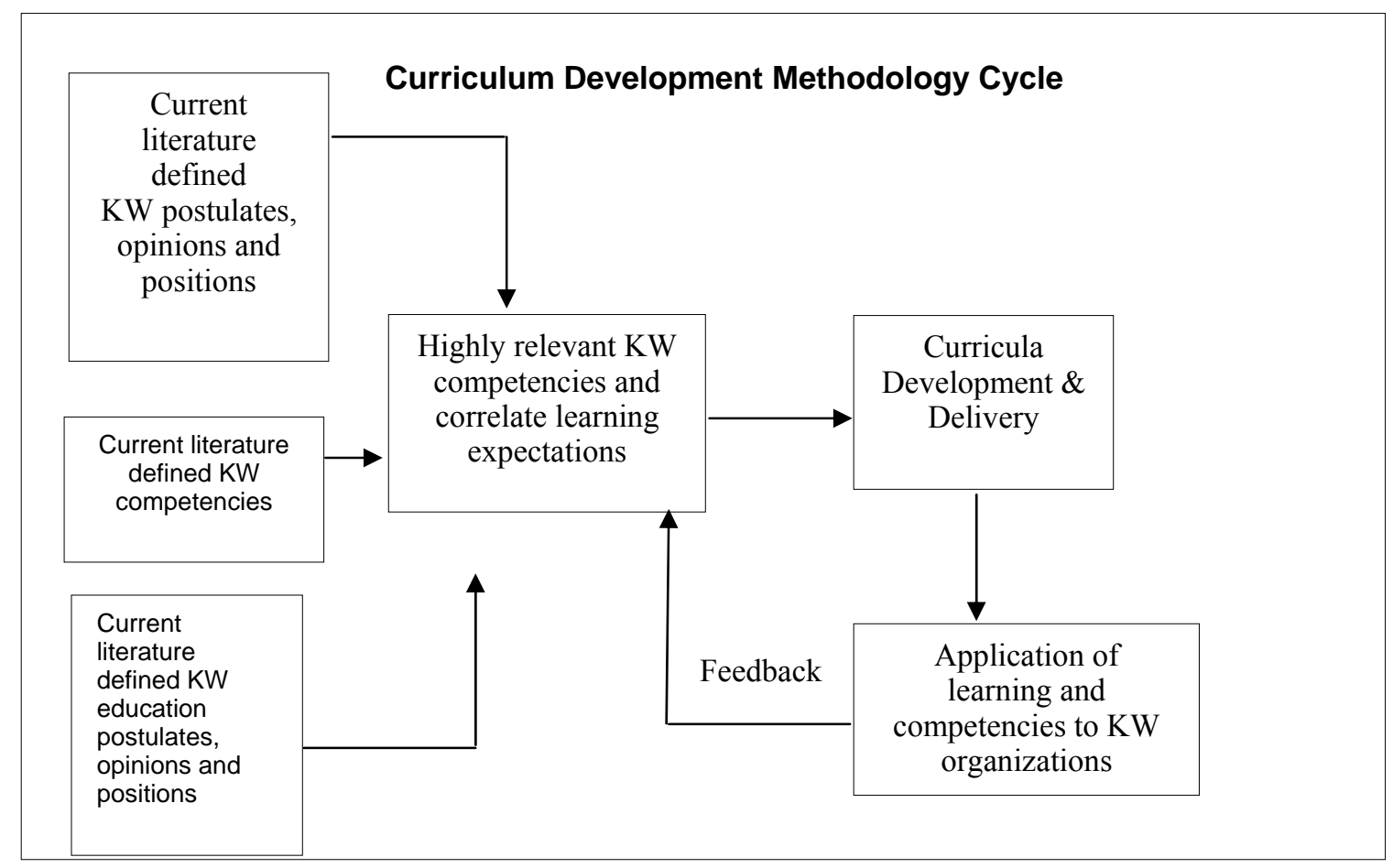

\section{DATA SOURCES}

Four sources of data were used. First, potential survey questions were identified and assembled from a review and compilation of the literature. The literature search identified fifty-two management research authored assertions (Appendix A) that were ultimately used to develop a thirty-five question survey instrument. The second and third data sources (demographic and categorical variables) were student and faculty questionnaire responses. The fourth source was data gathered via interviews conducted with technical and non-technical students, managers, and educators.

\section{RESEARCH QUESTIONS}

The research questions addressed in this project include: (A) What are the $21^{\text {st }}$ century management theorists' assertions that reflect concepts required for effectively managing KWs, as related to designing a graduate business degree curriculum? (B) Are $21^{\text {st }}$ century management theorists' assertions addressed in specific KW management programs to affect desired didactic outcomes? (c) Are $21^{\text {st }}$ century management theorists' assertions germane in effectively managing KWs?

\section{HYPOTHESES}

H1: There is significant agreement as to the prioritization of literature defined opinions, postulates and positions, among management school targeted student populations, today's KW educators and today's KW managers.

H2: There is significant agreement as to the prioritization of literature defined KW competencies between the management school targeted student populations, today's KW educators and today's KW managers.

H3: There is significant agreement as to the prioritization of literature defined KW training didactics between the management school targeted student populations, today's KW educators and today's KW managers. 


\section{SURVEY INSTRUMENT}

The initial survey instrument comprised of 52 assertions (Appendix A), was pilot tested on a formative group of $30 \mathrm{KW}$ students participating in a management program. Interviewer observations and respondent feedback identified specific issues, and a Split-Halves Measurement of Reliability (Kerlinger 1995) detected some bias. The defective questions were checked against literature sources for accuracy and were either reworded or discarded, leaving the thirty-five question survey instrument that was ultimately used.

\section{SURVEY QUESTION CONSTRUCTS}

The administered survey contains three demographic questions (A, B, C) and 35 categorical questions. Each categorical question response was measured using a Likert scale measurement (Kerlinger, 1995), and each was assessed using an ordinal-scaled measurement. A five point Likert scale was applied as follows: $(1=$ slightly disagree, $2=$ moderately disagree, $3=$ neither disagree nor agree, $4=$ moderately agree, $5=$ strongly agree). The responses were subsequently counted by level of agreement and a categorical group mean was derived. Each demographic question was measured, counted by segmented groups, and a group mean as well as a group median were derived (Zikmund, 2000).

\section{DATA ANALYSIS}

Sample Size: All questionnaire responses were compilated, sorted and counted using a Microsoft ${ }^{\circledR}$ Excel data format. This created a mutually exclusive bifurcated data base composed of sample sizes 197 (KW/students) and 53 (educators).

Hypothesis Testing: The Kruskal-Wallis Rank Test for differences in means was used to test the three hypotheses (Group I - Postulates, Opinions, and Theories, Group II - Competencies, Group III - Training Issues.) These three groups of questions were hypothesis tested against the four stratified population groups: technical workers, non-technical workers, managers, and educators. According to Levine, Stephan, Krehbiel, Berenson (2001), the non-parametric Kruskal-Wallis test is analogous to the parametric pooled-variance $t$ test for independent samples, and enables independence testing between sample groups having been drawn from the same population. The null hypotheses are stated:

Ho: $\mathrm{M} 1=\mathrm{M} 2=\mathrm{M} 3=\mathrm{Mc}$.

That is, Ho1: M1= M2..M14; Ho2: M15=M16 .. M24; and Ho3: M25=M26 .. M35.

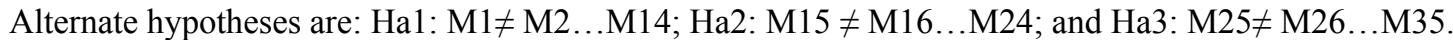

The Kruskal-Wallis Rank Test For Differences in c Means: $H=\left[12 / n(n+1) \sum T^{2}{ }_{j} / n_{j}\right]-3(n+1)$

Where:

$\mathrm{n}=$ total number of observations over the combined samples

$\mathrm{n}_{\mathrm{i}}=$ number of observations in the jth sample

$\mathrm{T}_{\mathrm{i}}=$ sum of the ranks assigned to the jth sample

$\mathrm{T}^{2}{ }_{\mathrm{i}}=$ square of the sum of the ranks assigned to the jth sample.

The Kruskal-Wallis Rank test was run at a 0.05 level of significance at a c-1 degree of freedom $(\mathrm{Ho}=\mathrm{c} 13$, $\mathrm{H} 1=\mathrm{c} 9$, and $\mathrm{H} 2=\mathrm{c} 9$ ). The decision rule was to reject the null hypothesis if Ho was less than or equal to $\mathrm{X}^{2} \mathrm{U}$ (area of rejection.)

A second non-parametric test, Wilcoxon Rank Sum Test for Differences Between Two Means, was also used to test differences between intra-group populations that demonstrated significant differences in the Kruskal-Wallis test of the three null hypotheses (Ho1, Ho2, and Ho3). The Wilcoxon Rank Sum Test was used to detect differences between intra-group mean pairs. According to Levine, Stephan, Krehbiel, Berenson (2001, p. 402), "this 
nonparametric procedure can be used for testing differences between means of two populations where the stringent assumptions of the $t$ test cannot be met."

\section{RESULTS - DEMOGRAPHICS}

Three demographic categories were compiled for this research. First, a job classification demographic was segmented and counted from questionnaire inputs. The ten job classifications were: clerical, sales/marketing, trades, technical, professional, professional/ student, manager, executive, educator and other. Table 1, Appendix C, is a count by job classification category. Further, when the ten job classifications were sorted and counted, of 250 interviewed, $39.33 \%$ classified themselves as a KWs (Professionals or Technical/Trades) (Drucker, 1999).

Age grouping was the second demographic variable counted. This variable was segmented and counted from the questionnaire inputs administered to the non-educator sample. The seven age categories were grouped as follows: 18 to 25,26 to 35,36 to 45,46 to 55,56 to $65,65+$, and no answer. It should be noted that the two highest counts came from the 26 to 35 age group at $27.41 \%$ and the 36 to 45 age group at $26.90 \%$. The group median was derived as 34 years of age.

The third demographic measured was industry catagory. Table 1 is a count by industry category and shows that the traditional industry classifications account for $51.78 \%$, however, fully $48.22 \%$ account for industries with high knowledge worker concentrations. While traditional industry classifications account for $51.78 \%, 48.22 \%$ account for industries with high knowledge worker concentrations (See Table 1).

\begin{tabular}{|l|c|c|c|}
\hline \multicolumn{1}{|c|}{ Industry } & Count & Percent & T Cuml. Percent \\
\hline Manufacturing & 17 & $8.63 \%$ & \\
\hline Government & 10 & $5.08 \%$ & $6.09 \%$ \\
\hline Retail/Marketing & 12 & $12.18 \%$ & $51.78 \%$ \\
\hline Other & 24 & $19.80 \%$ & $17.77 \%$ \\
\hline blank & 39 & $4.06 \%$ & $13.20 \%$ \\
\hline Entrepreneur/consulting & 35 & $\mathbf{1 3 . 2 0 \%}$ & $\mathbf{4 8 . 2 2 \%}$ \\
\hline Utilities/media & 8 & $100.00 \%$ & $100.00 \%$ \\
\hline Health care & 26 & & \\
\hline Banking/finance/ins. & 26 & & \\
\hline
\end{tabular}

\section{RESULTS - CATEGORICAL - KRUSKAL-WALLIS RANK TEST:}

Kruskal-Wallis Test 1 was run at a 0.05 level of significance. The three question groups generated the following sum of ranks: Group 1 (non-technical) $=349.5$, Group 2 (technical $)=372$, Group 3 (manager) $=416.5$, and Group 4 (educator) $=458$. The test results had an $\mathrm{H}$ test statistic of 1.8707 , a critical value of 7.8147 , and a $p$-value of 0.59967 , therefore accepting the null hypothesis (Ho1).

H1: There is significant agreement as to the prioritization of literature defined opinions, postulates and positions between the management school targeted student populations, today's KW educators and today's KW managers.

Kruskal-Wallis Test 2 was also run at a 0.05 level of significance. The three question groups generated the following sum of ranks: Group1 (non-technical) $=72$, Group 2 (technical) $=227.5$, Group 3 (manager) $=365$, and Group 4 (educator) $=325.5$. The test results had an $\mathrm{H}$ test statistic of 28.149 , a critical value of 7.8147, and a p-value of 3.3806, therefore rejecting the null hypothesis (Ho2).

H2: There is significant agreement as to the prioritization of literature defined KW competencies, between the management school targeted student populations, today's KW educators and today's KW managers. 
Kruskal-Wallis Test 3 was run at a 0.05 level of significance. The three question groups generated the following sum of ranks: Group1 (non-technical) $=235$, Group 2 (technical) $=213$, Group 3 (manager) $=229$, and Group 4 (educator) $=143$. The test results had an $\mathrm{H}$ test statistic of 3.9395, critical value of 7.8147, and p-value of 0.26807 , therefore accepting the null hypothesis (Ho3).

H3: There is significant agreement as to the prioritization of literature defined KW training didactics, between the management school targeted student populations, today's KW educators and today's KW managers.

\section{RESULTS - CATEGORICAL - WILCOXON RANK SUM TEST}

After Kruskal-Wallis Test 2 recommended rejection of Ho2 (significant agreement as to the prioritization of literature defined KW competencies between the management school targeted student populations, today's KW educators and today's KW managers), Wilcoxon Rank Sum Tests were run on Ho2 to determine if any intra-group paired relationships exist. Despite the Kruskal-Wallis Test 2 recommended rejection, that is to say all groups were not in agreement as to ranking of the group two questions, researchers did find certain intra-group ranking agreement.

For Ho2, Wilcoxon Rank Sum Test A was run at a .05 level of significance. Sample population 1 (nontechnical) sum of ranks was 70, while sample population 2 (technical) sum of ranks was 183 . A two tail test had a $+/-$ critical value of 1.9596 and a T1 test statistic of 70 . The $Z$ test statistic was -3.71 with a $p$ value of 0.00021 . Test $A$ results therefore recommended rejecting the sub-hypothesis that intra group (non-technical and technical) demonstrate similar rankings for Hypothesis Two.

Again for Ho2, Wilcoxon Rank Sum Test B was run at a .05 level of significance. Sample population 3 (managers) sum of ranks was 140, while sample population 4 (educators) sum of ranks was 113. A two tail test had a $+/$ - critical value of 1.9596 and a T1 test statistic of 140 . The $Z$ test statistic was 0.8864 with a $p$ value of .37536 . Test $\mathrm{B}$ results did not reject the sub-hypothesis that intra group (managers and educators) have similar rankings for Hypothesis Two. Therefore, researchers inferred an agreement on ranking between managers and educators for group two questions regarding the prioritization of literature defined KW competencies.

\section{CONCLUSIONS}

The US and other developed nations must address knowledge worker issues to maintain their competitive position in the world economy, especially in light of the significant demographic assets engaged in knowledge work today. Researchers such as Richards-Wilson (2002), Laing (2003), and Maule (2001) have questioned if today's business schools' profile of the $\mathrm{KW} /$ student remains on target. This study reveals a definite demographic characteristic shift toward a newly defined student that is more mature (median age at 34 years old), $48 \%$ likely to be working in a high technology driven environment, and 39\% likely to consider themselves a professional or technoservice worker. Additional research may explain if we are attempting to educate a bifurcated student population or if a significant shift in the business school population has actually occurred. The three study demographic findings show a paradigm change to more Professional, Technical, or Trade job title classification use. Standard industry classification concentration changes to classifications with high technical worker classifications and an experiential level demand change to older ( 36 to 45 years old) and experienced workers (10+ years experience). These demographic paradigm changes were previously addressed by Austin (1999), Clark (2003), Drucker (1999), and others.

According to the findings of this study, knowledge worker productivity can be directly related to the workplace environment in which KWs can continue to learn and apply their knowledge. Innovation and learning are critical elements of knowledge worker organizations. This study found inter sample group ranking agreement between only four knowledge worker literature-defined opinions, postulates and positions (Assertions -Appendix A). The four literature-defined opinions, postulates and positions included: (I) Knowledge worker level of success is a direct result of the de-concentration of power (Thomas and Friedman, 1999); (II) The most valuable asset of a 20th-century institution, whether business or non-business, will be its knowledge workers and their productivity (Drucker, 1999); (III) Knowledge workers require a workplace environment in which they can continue to learn and apply their knowledge (Townsend, DeMarie \& Hendrickson, 1998); and (IV) For economies based on knowledge work, innovation and learning are critical elements of organizations (Marquardt \& Berger, 2000.) 
This research shows significant agreement as to the prioritization of literature defined $\mathrm{KW}$ training didactics between management school targeted student populations, today's KW educators and today's KW managers. All four sample populations agreed that knowledge worker organizational priorities should be ranked as follows: (1) Motivation, critical thinking, personnel and conflict resolution skills are essential elements in effective management in the knowledge worker organization (Whetten \& Cameron, 2002); (2) Knowledge worker students are most motivated to learn when the subject matter is seen as immediately relevant to their lives and has practical applications (Charner \& Rolzinski, 1997); (3) Knowledge worker students find interactive learning environments more effective than passive learning environments (Smith, Boyatzis \& Cowen, 1995); and (4) Knowledge worker students are highly goal oriented and appreciate an educational program that is well organized with clearly defined elements (Charner \& Rolzinski, 1997).

According to The Economist (2004), applications to business schools are down in the United States, yet these same business schools still award $85 \%$ of the world's business degrees. The downward demand appears to be an international phenomenon. This study suggests that more research is needed to establish validity and relevancy for teaching didactics, classroom delivery systems, and instructor-perceived values of today's KW/students. As KW industry-driven competencies and technology standards are culturally ingrained into the 21 st century $\mathrm{KW} /$ student environment, it is essential for educators to create relevant strategies and teaching methods to meet their needs in an environment not alien to the knowledge-worker (Mintzberg, 2004).

\section{STUDY LIMITATIONS}

This research was limited by a stratified population: South Florida (United States) students and educators from this same universe. Postulates, theories and concepts tested were limited to the scope of the literature undertaken.

\section{RECOMMENDATIONS FOR FUTURE RESEARCH}

Future studies should increase the population universe to other areas of North America as well as diverse cultures where KW environments are also rapidly growing, such as Europe, India, and Japan. Solicitation of more traditional students into the studied universe for comparative analysis would generate a fifth sample population group for a more cross sectional comparison. Finally, a feedback process should be developed and implemented so that relevant $\mathrm{KW} /$ student issues and didactics can be addressed within existing business and management school frameworks.

\section{REFERENCES}

1. Association to Advance Collegiate Schools of Business. April, 2002. Management education at risk: a report from the management education task force.

2. Austin, R.D. 1999. Managing knowledge workers: evolving practices and trends. Next wave Science, 4:2530 .

3. Bass, B.M. 1990. Bass \& Stogdill's handbook of leadership: theory, research, and managerial application $\left(3^{\text {rd }}\right.$ ed.) New York: Free Press.

4. Boyatzis, R.E., Cowen, S.S., \& Kolb, D.A. 1995. Introduction: taking the path toward learning. innovation in professional education: steps on a journey from teaching to learning: 32-49. San Francisco: Jossey-Bass.

5. Cappelli, P. 1992. College students and the workplace: assessing performance to improve the fit. Change, 5561, November/December.

6. Carrison, D., \& Walsh, R. 1998. Semper fi: business leadership the marine corps way. New York: AMACOM.

7. Charner, I. \& Rrozinski, C. (Eds). 1997. Responding to the educational didactics of today's workplace. San Francisco: Jossey Bass, Inc.

8. Clark, J. M. 2003. Developing competency-driven learning content. Chief learning officer, 2(5):34-37.

9. Conger, J. 1994. Learning to lead: the art of transforming managers into leaders. San Francisco: JosseyBass.

10. Conger, J. \& Benjamin, B. 1999. Building leaders: how successful companies develop the next generation. San Francisco: Jossey Bass, Inc. 
11. Crow, S.D. 2001, March. Serving the common good: consultant - evaluators in the heart of peer reviews. [Online]. Available: http://www.ncahigherlearning commission.org/AnnualMeeting/archive/ [5 June 2001].

12. Doria, J., Rozanski, H., \& Cohen, E. 2003, What business really didactics from b-schools. Strategy + Business, 39-45, Fall.

13. Drucker, P.F. 1997. The future that has already happened. Harvard Business Review. 75(5):20-23.

14. Drucker, P.F. 1999. Management challenges for the $21^{\text {st }}$ century. New York: HarperBusiness.

15. Friedman, T.L. 1999. The lexus and the olive tree. New York: Anchor.

16. Gibney, M, Smith, C; Barclay, N; Rosenfield, Robert. 2002. Domain logics of strategy in further education colleges. Research in post-compulsory education, 7:45-61.

17. Goleman, D. 1995. Emotional intelligence. New York: Bantam Books.

18. Greiner, L.E., Bhambri, A., \& Cummings, T.G. 2003. Searching for a strategy to teach strategy. Academy of management learning and education, 2(4):402-420.

19. Kerlinger, F. 1996. Foundations of behavioral research. New York: Holt, Rinehart and Winston, Inc.

20. Knowledge workers are the new capitalists. 2001. The Economist, 265:60, Nov 1.

21. Kouzes, J.M. \& Posner, B.Z. 1995. The leadership challenge. San Francisco: Jossey Bass, Inc.

22. Levine, D.M., Stephan, D., Krehbiel,T.C., \& Berenson, M.L. 2002. Statistics for managers using Microsoft ${ }^{\circledR}$ Excel. Prentice Hall, Upper Saddle River, New Jersey.

23. Marquardt, M.J. \& Berber, N.O. 2000. Global leaders of the $21^{\text {st }}$ century. Albany: State University of New York Press.

24. Mason, R., Lind, D., \& Marchal W. 1999. Nonparametric methods: analysis of ranked data (In Statistical Techniques in Business and Economics). Boston, MA: p.541-574.

25. Mintzberg, H. 2003. Managers Not MBAs. Berrett-Koehler Publishers, Inc., San Francisco, California.

26. Porter, L.W. \& McKibbins, L.F. 1988. Management education and development: Drift or thrust into the 21st century? New York: McGraw Hill.

27. Rozanski, M. 2003. The why and how of collegiate international education consortia. California Journal of Teacher Education. 10:72-83, Winter.

28. ryes, S.L., Trank, C.Q., Lawson, A.M., \& Ilies, R. 2003. Behavioral coursework in business education: growing evidence of a legitimacy crisis. Academy of Management Learning and Education, 2(3):269-283.

29. senge, P. 1992. The leaders of new work: building learning organizations. New traditions in business: spirit and leadership in the $21^{\text {st }}$ century. San Francisco: Berrett-Koehler Publishers.

30. Special report: But can you teach it? 2004. The Economist, 371:81, May 22.

31. Study: knowledge workers in Canada's workforce. 2003. The Daily, [Online]. Available: http://www.statcan.ca. [4 Feb 2004]

32. Tas, R. 1988. Teaching future managers. The Cornell hotel and restaurant administration quarterly. 29:4143.

33. Tas, R., Okeiti, E, Finley, D., \& Postel, R. 1994. Food and beverage management competencies: educator, industry, and student perceptive. Hospitality \& tourism educator. 6:64, Fall.

34. Townsend, A.M., DeMarie, S.M., \& Hendrickson, A. R. 1998. Virtual teams: technology and the workplace of the future. The Academy of Management Executive, 12(3):17-29.

35. Varcoe, K. E. (2000). Evaluation methodology learning activity package. Ft. Lauderdale, FL: Nova Southeastern University, Programs for Higher Education.

36. Whetten, D.A. \& Cameron, K.S. 2002. Developing management skills. New Jersey: Prentice Hall.

37. Wilson, J. \& Wong, K., Learning style preferences and implications for training programs in the hospitality and tourism industry. Journal of hospitality \& tourism education, 12(2):32-40.

38. Zaccaro S.J., Mumford, M.D., Connelly, M.S., MarkS, M.A., \& Gilbert, J.A. 2000. Assessment of leader problem-solving capabilities. Leadership Quarterly, 11(1):37-64.

39. Zikmund, W. 2000. Data Analysis \& Presentation. (In Business Research Methods, $7^{\text {th }}$ Ed), The Dryden Press, Orlando, FL: p.505-584. 


\section{Appendix A Assertions}

\begin{tabular}{|c|c|c|c|}
\hline 1 & $\begin{array}{l}\text { Knowledge worker productivity is likely to be the central issue for } 21 \mathrm{st}^{\prime} \\
\text { century organizations }\end{array}$ & Drucker, PR & 1999 \\
\hline 2 & $\begin{array}{l}\text { The most valuable assets of a } 21^{\text {st }} \text { century company were its production } \\
\text { equipment. }\end{array}$ & Drucker, PR & 1999 \\
\hline 3 & $\begin{array}{l}\text { The most valuable asset of a } 21^{\text {st }} \text { century institution, whether business or non- } \\
\text { business, will be its knowledge workers and their productivity. }\end{array}$ & Drucker, PR & 1999 \\
\hline 4 & $\begin{array}{l}\text { Management theory and practice has moved from managing the work of } \\
\text { people to managing their performance. }\end{array}$ & Drucker, PR & 1999 \\
\hline 5 & $\begin{array}{l}\text { The goal of management theory and practice today is to make people more } \\
\text { productive using the specific strengths and knowledge of each worker. }\end{array}$ & Drucker, PR & 1999 \\
\hline 6 & $\begin{array}{l}\text { The only way for developed countries to maintain their competitive position in } \\
\text { the world economy today is to improve the productivity of knowledge workers. }\end{array}$ & Drucker, PR & 1999 \\
\hline 7 & $\begin{array}{l}\text { The productivity of knowledge and knowledge workers will be the most } \\
\text { important competitive factor in the world economy. }\end{array}$ & Drucker, PR & 1999 \\
\hline 8 & $\begin{array}{l}\text { One of foremost principles of } \mathrm{KW} \text { management is an emphasis on } \\
\text { relationships. }\end{array}$ & Austin & 2002 \\
\hline 9 & $\begin{array}{l}\text { One of foremost principles of KW management is an emphasis on iterative } \\
\text { work structures (rather than linear, sequential ones) which are characterized by } \\
\text { alternating periods of unstructured and structured work. }\end{array}$ & Austin & 2002 \\
\hline 10 & $\begin{array}{l}\text { Knowledge workers need a workplace structure where they can continue to } \\
\text { learn and apply their knowledge. }\end{array}$ & Austin & 2002 \\
\hline 11 & $\begin{array}{l}\text { Knowledge workers require a high level of competency in higher-order } \\
\text { cognitive skills such as critical thinking and problem solving. }\end{array}$ & $\begin{array}{l}\text { Townsend, } \\
\text { DeMarie \& } \\
\text { Hendrickson }\end{array}$ & 1998 \\
\hline 12 & $\begin{array}{l}\text { Knowledge worker level of success is a direct result of the democratizations of } \\
\text { technology, information, and decision-making. }\end{array}$ & $\begin{array}{l}\text { Thomas and } \\
\text { Friedman }\end{array}$ & 1999 \\
\hline 13 & $\begin{array}{l}\text { Knowledge worker level of success is a direct result of the de-concentration of } \\
\text { power. }\end{array}$ & $\begin{array}{l}\text { Thomas and } \\
\text { Friedman }\end{array}$ & 1999 \\
\hline 14 & $\begin{array}{l}\text { Knowledge worker organizations require people on the outer edges of } \\
\text { organizations to solve complex problems because the enormously } \\
\text { complex and large globalization information systems now rests in the hands of } \\
\text { these individuals. }\end{array}$ & $\begin{array}{l}\text { Thomas and } \\
\text { Friedman }\end{array}$ & 1999 \\
\hline 15 & $\begin{array}{l}\text { With the access of information only a keystroke away, power has shifted from } \\
\text { those with titles to those with the technology and skills to use it in knowledge } \\
\text { worker organizations, today. }\end{array}$ & $\begin{array}{l}\text { Kouzes and } \\
\text { Posner }\end{array}$ & 1995 \\
\hline 16 & $\begin{array}{l}\text { Because the new global economy is based on knowledge work, there is a } \\
\text { convergence between work and learning in today's organization. }\end{array}$ & Senge & 1992 \\
\hline 17 & $\begin{array}{l}\text { Information, processed by human brain work into meaningful knowledge, has } \\
\text { become the world's most important resource. }\end{array}$ & $\begin{array}{c}\text { Marquardt \& } \\
\text { Berger }\end{array}$ & 2000 \\
\hline 18 & $\begin{array}{l}\text { Information is more important than physical labor, minerals, and energy in } \\
\text { today's organization. }\end{array}$ & $\begin{array}{l}\text { Marquardt \& } \\
\text { Berger }\end{array}$ & 2000 \\
\hline 19 & $\begin{array}{l}\text { Diversity, reflects a workforce that is growing more diverse not only in race, } \\
\text { ethnicity, and gender, but also to the extent to which employees affiliate with a } \\
\text { single institution with a growing employment of contingent or part-time and } \\
\text { temporary workers. }\end{array}$ & $\begin{array}{l}\text { Marquardt \& } \\
\text { Berger }\end{array}$ & 2000 \\
\hline 20 & $\begin{array}{l}\text { Knowledge worker organization managers in the new millennium must } \\
\text { become cross-culturally adept, as many will work for multinational } \\
\text { corporations. }\end{array}$ & $\begin{array}{l}\text { Marquardt \& } \\
\text { Berger }\end{array}$ & 2000 \\
\hline 21 & $\begin{array}{l}\text { Due to rapid change, achievement of personal growth goals is a critical } \\
\text { demand of workers. }\end{array}$ & $\begin{array}{l}\text { Naisbitt \& } \\
\text { Aburdene }\end{array}$ & 1985 \\
\hline 22 & $\begin{array}{l}\text { Due to rapid change, organizations need to help facilitate the process of } \\
\text { personal growth goals. }\end{array}$ & $\begin{array}{l}\text { Naisbitt \& } \\
\text { Aburdene }\end{array}$ & 1985 \\
\hline 23 & $\begin{array}{l}\text { Today's organizations will require a renewed investment in training programs } \\
\text { that are designed to develop the key competencies that have a direct impact on } \\
\text { the performance of today's global workforce. }\end{array}$ & Clark & 2003 \\
\hline 24 & $\begin{array}{l}\text { Tremendous amounts of training dollars are spent annually in developing } \\
\text { managerial competencies because higher education has either been slow in } \\
\text { addressing these concerns or have been inadequate in its efforts. }\end{array}$ & Clark & 2003 \\
\hline
\end{tabular}




\begin{tabular}{|c|c|c|c|}
\hline 25 & $\begin{array}{l}\text { Technology is changing almost every single workplace, requiring that people } \\
\text { have higher-level competencies in order to succeed. }\end{array}$ & Crow & 2001 \\
\hline 26 & $\begin{array}{l}\text { Technology is changing almost every single workplace, requiring that people } \\
\text { are capable of engaging in self-directed lifelong learning. }\end{array}$ & Crow & 2001 \\
\hline 27 & $\begin{array}{l}\text { Business education should be more applied, helping students see the links to } \\
\text { practice, and interpersonal and leadership skills should be emphasized with a } \\
\text { greater focus on managing people. }\end{array}$ & $\begin{array}{l}\text { Porter \& } \\
\text { McKibbins }\end{array}$ & 1998 \\
\hline 28 & $\begin{array}{l}\text { Today, new business course offerings in nontraditional areas of business do not } \\
\text { lead to necessary changes in the all-important core course work, or in the ways } \\
\text { in which students are being taught. }\end{array}$ & $\begin{array}{l}\text { Rozanski \& } \\
\text { Cohen }\end{array}$ & 2003 \\
\hline 29 & $\begin{array}{l}\text { The neglect of behavioral and implementation training in business school } \\
\text { curriculum results in students graduating with strong conceptual expertise but } \\
\text { weak skills in applying it to achieve positive results. }\end{array}$ & $\begin{array}{l}\text { Greiner, } \\
\text { Bhambri \& } \\
\text { Cummings }\end{array}$ & 2003 \\
\hline 30 & $\begin{array}{l}\text { Analytical expertise without the complementary behavioral skills to involve } \\
\text { others in the total process can result in both badly formulated } \\
\text { strategies and failed implementation. }\end{array}$ & $\begin{array}{l}\text { Greiner, } \\
\text { Bhambri \& } \\
\text { Cummings }\end{array}$ & 2003 \\
\hline 31 & $\begin{array}{l}\text { Companies still find that they must provide "remedial" behavioral education to } \\
\text { their new hires in order to close the gaps that students did not fill while in } \\
\text { college. }\end{array}$ & $\begin{array}{l}\text { Ryes, Trank, } \\
\text { Lawson \& } \\
\text { Ilies }\end{array}$ & 2003 \\
\hline 32 & $\begin{array}{l}\text { There is growing evidence that behavioral competencies (i.e., skills) are, in } \\
\text { fact, teachable through a combination of theory \& practice. }\end{array}$ & $\begin{array}{l}\text { Ryes, Trank, } \\
\text { Lawson \& } \\
\quad \text { Ilies }\end{array}$ & 2003 \\
\hline 33 & $\begin{array}{l}\text { There is evidence that social and behavioral skills are partially determined } \\
\text { early in life; they can be learned and improved upon exposure to theoretical } \\
\text { principles and practices. }\end{array}$ & $\begin{array}{l}\text { Carrison \& } \\
\text { Walsh; } \\
\text { Conger; } \\
\text { Goleman }\end{array}$ & $\begin{array}{l}1998 \\
1994 \\
1995\end{array}$ \\
\hline 34 & $\begin{array}{l}\text { Effective administration depends on three basic personal skills: technical, } \\
\text { human and conceptual. }\end{array}$ & Bass & 1990 \\
\hline 35 & $\begin{array}{l}\text { Leadership capabilities can be developed over time through education and } \\
\text { experience, and frames leadership in terms of the knowledge and skills that } \\
\text { make effective leadership possible. }\end{array}$ & $\begin{array}{l}\text { Mumford, } \\
\text { Zaccaro, } \\
\text { Harding, et al }\end{array}$ & 2004 \\
\hline 36 & $\begin{array}{l}\text { Competencies are the key factors that account for effective performance. The } \\
\text { three competencies of problem-solving skills, social judgment skills, and } \\
\text { knowledge are at the heart of the skills-based model. }\end{array}$ & $\begin{array}{l}\text { Mumford, } \\
\text { Zaccaro, } \\
\text { Harding, et al }\end{array}$ & 2004 \\
\hline 37 & $\begin{array}{l}\text { Leadership outcomes are the direct result of a leader's competencies and each } \\
\text { of these include a large repertoire of abilities which can be learned and } \\
\text { developed. }\end{array}$ & $\begin{array}{l}\text { Mumford, } \\
\text { Zaccaro, } \\
\text { Harding, et al }\end{array}$ & 2004 \\
\hline 38 & $\begin{array}{l}\text { Motivation, critical thinking, personality, and conflict resolution, are issues of } \\
\text { personal effectiveness in the modern workplace. }\end{array}$ & $\begin{array}{l}\text { Whetten \& } \\
\text { Cameron }\end{array}$ & 2002 \\
\hline 39 & $\begin{array}{l}\text { Behavioral principles must be grounded in social science theory and in reliable } \\
\text { research results. }\end{array}$ & $\begin{array}{l}\text { Whetten \& } \\
\text { Cameron }\end{array}$ & 2002 \\
\hline 40 & $\begin{array}{l}\text { Individuals must be aware of their current level of skill competency and be } \\
\text { motivated to improve. }\end{array}$ & $\begin{array}{l}\text { Whetten \& } \\
\text { Cameron }\end{array}$ & 2002 \\
\hline 41 & $\begin{array}{l}\text { Business schools need an application component in their learning environment } \\
\text { that includes exercises to apply classroom learning to examples from the real } \\
\text { world. }\end{array}$ & $\begin{array}{l}\text { Whetten \& } \\
\text { Cameron }\end{array}$ & 2002 \\
\hline 42 & $\begin{array}{l}\text { Business school programs using an applications component learning model has } \\
\text { shown that it produces results superior to those based on more traditional } \\
\text { lecture-discussion-case method approach. }\end{array}$ & $\begin{array}{l}\text { Smith, } \\
\text { Boyatzis, } \\
\text { Cowen }\end{array}$ & 1995 \\
\hline 43 & $\begin{array}{l}\text { A curriculum, with the educational philosophy that views learning as a } \\
\text { development process must occur over extended lengths of time, is more } \\
\text { successful than those that do not. }\end{array}$ & Crow & 2004 \\
\hline 44 & $\begin{array}{l}\text { A curriculum with the educational philosophy that strictly applies lecture } \\
\text { approach is severely limited in its ability to address the future didactics of } \\
\text { managers and instructors. }\end{array}$ & Crow & 2004 \\
\hline 45 & $\begin{array}{l}\text { A curriculum with the educational philosophy to develop processes that } \\
\text { emphasize the creation of interactive learning environments rather than merely } \\
\text { presenting information to passive students, is more successful than those that } \\
\text { do not approach. }\end{array}$ & $\begin{array}{l}\text { Smith, } \\
\text { Boyatzis, } \\
\text { Cowen }\end{array}$ & 1995 \\
\hline
\end{tabular}




\begin{tabular}{|c|c|c|c|}
\hline 46 & $\begin{array}{l}\text { Faculty teaching and role modeling as a coach helps students understand what } \\
\text { it might look like for them in the workplace. }\end{array}$ & Crow & 2004 \\
\hline 47 & $\begin{array}{l}\text { The adult learning movement is, in many ways, at the vanguard leading higher } \\
\text { education into the } 21^{\text {st }} \text { century. }\end{array}$ & $\begin{array}{l}\text { Smith, } \\
\text { Boyatzis, } \\
\text { Cowen }\end{array}$ & 1995 \\
\hline 48 & $\begin{array}{l}\text { Educational programs need to do a better job of leveraging adult learning } \\
\text { principles in order to translate abstract learning principles into a meaningful } \\
\text { educational experience. }\end{array}$ & Crow & 2001 \\
\hline 49 & $\begin{array}{l}\text { Educational programs need to set a cooperative learning climate and create } \\
\text { mechanisms for mutual planning. }\end{array}$ & Crow & 2001 \\
\hline 50 & $\begin{array}{l}\text { Students today are most motivated for learning when it is immediately relevant } \\
\text { to their lives and has a practical application. }\end{array}$ & $\begin{array}{l}\text { Charner \& } \\
\text { Rolzinski }\end{array}$ & 1997 \\
\hline 51 & $\begin{array}{l}\text { Research suggests that students today are goal-oriented and appreciate an } \\
\text { educational program that is well-organized and has clearly defined elements. If } \\
\text { the program objectives include skill-building and a well-designed planned } \\
\text { didactic, an improved classroom process results. }\end{array}$ & $\begin{array}{l}\text { Charner \& } \\
\text { Rolzinski }\end{array}$ & 1997 \\
\hline 52 & $\begin{array}{l}\text { Research suggests that organizations that hire students who have developed } \\
\text { these managerial competencies should also incur lower training and } \\
\text { development costs. }\end{array}$ & Cappelli & 1992 \\
\hline
\end{tabular}

\section{Appendix B}

Table 5 - Count by Question and Response ( $N=197)$

\begin{tabular}{|c|c|c|c|c|c|c|c|c|c|c|c|c|c|c|}
\hline $\begin{array}{l}\text { Group } \\
1 \\
\text { Qstns } \\
\end{array}$ & $\begin{array}{l}\text { Qstn } \\
1 \\
\end{array}$ & $\begin{array}{l}\text { Qstn } \\
2 \\
\end{array}$ & $\begin{array}{l}\text { Qstn } \\
3 \\
\end{array}$ & $\begin{array}{l}\text { Qstn } \\
4 \\
\end{array}$ & $\begin{array}{l}\text { Qstn } \\
5 \\
\end{array}$ & $\begin{array}{l}\text { Qstn } \\
6 \\
\end{array}$ & $\begin{array}{l}\text { Qstn } \\
7 \\
\end{array}$ & $\begin{array}{l}\text { Qstn } \\
\mathbf{8} \\
\end{array}$ & $\begin{array}{l}\text { Qstn } \\
9 \\
\end{array}$ & $\begin{array}{l}\text { Qstn } \\
10 \\
\end{array}$ & $\begin{array}{l}\text { Qstn } \\
11\end{array}$ & $\begin{array}{l}\text { Qstn } \\
12 \\
\end{array}$ & $\begin{array}{l}\text { Qstn } \\
13 \\
\end{array}$ & $\begin{array}{l}\text { Qstn } \\
14 \\
\end{array}$ \\
\hline Non-tech & 4.09 & 4.00 & 4.27 & 3.78 & 4.27 & 3.65 & 3.74 & 3.44 & 4.22 & 3.47 & 3.80 & 4.03 & 4.29 & 3.58 \\
\hline Tech & 4.11 & 3.91 & 4.23 & 3.99 & 4.19 & 3.96 & 3.65 & 3.46 & 4.23 & 3.56 & 3.87 & 4.10 & 4.28 & 3.52 \\
\hline Mgt. & 4.17 & 4.04 & 4.23 & 3.69 & 4.27 & 3.90 & 3.90 & 3.60 & 4.31 & 3.87 & 4.00 & 4.07 & 4.26 & 3.53 \\
\hline Educ. & 3.96 & 4.04 & 4.30 & 3.67 & 4.33 & 4.11 & 3.85 & 3.48 & 4.37 & 3.81 & 3.89 & 4.11 & 4.30 & 4.19 \\
\hline
\end{tabular}

\begin{tabular}{|c|c|c|c|c|c|c|c|c|c|c|c|}
\hline $\begin{array}{l}\text { Group } 2 \\
\text { Qstns }\end{array}$ & Qstn 15 & Qstn 16 & Qstn 17 & Qstn 18 & Qstn 19 & Qstn 20 & Qstn 21 & Qstn 22 & Qstn 23 & Qstn 24 & Qstn 25 \\
\hline Non-tech & 2.07 & 2.00 & 2.55 & 2.29 & 2.37 & 2.60 & 2.23 & 2.19 & 2.08 & 2.07 & 2.15 \\
\hline Tech & 2.46 & 2.81 & 2.79 & 2.57 & 2.93 & 2.56 & 2.64 & 2.64 & 2.75 & 2.67 & 2.65 \\
\hline Mgt. & 3.04 & 3.36 & 2.82 & 2.74 & 2.96 & 2.61 & 2.93 & 2.93 & 2.88 & 2.92 & 3.00 \\
\hline Educ. & 2.64 & 2.52 & 2.88 & 2.66 & 2.78 & 2.85 & 2.93 & 3.00 & 3.03 & 3.07 & 2.89 \\
\hline
\end{tabular}

\begin{tabular}{|c|c|c|c|c|c|c|c|c|c|c|}
\hline $\begin{array}{l}\text { Group } 3 \\
\text { Qstns } \\
\end{array}$ & Qstn 26 & Qstn 27 & Qstn 28 & Qstn 29 & Qstn 30 & Qstn 31 & Qstn 32 & Qstn 33 & Qstn 34 & Qstn 35 \\
\hline on-tech & 3.26 & 3.36 & 3.64 & 4.08 & 4.21 & 3.95 & 4.11 & 4.29 & 4.13 & 4.05 \\
\hline Tech & 3.62 & 3.63 & 3.75 & 3.99 & 4.05 & 3.99 & 4.06 & 4.34 & 4.06 & 3.93 \\
\hline Mgt. & 3.63 & 3.50 & 3.63 & 3.98 & 4.35 & 4.00 & 3.96 & 4.25 & 4.10 & 4.10 \\
\hline Educ. & 3.04 & 3.56 & 3.59 & 3.96 & 3.96 & 3.89 & 3.85 & 4.00 & 4.00 & 3.78 \\
\hline
\end{tabular}


Appendix C

Table 7 - Knowledge Worker Training

\begin{tabular}{|c|c|c|c|}
\hline Non Technical & Technical & Management & Education \\
\hline Qstn 33 & Qstn 33 & Qstn 30 & Qstn 33 \\
\hline Qstn 30 & Qstn 32 & Qstn 33 & Qstn 29 \\
\hline Qstn 34 & Qstn 34 34 & Qstn 30 \\
\hline Qstn 32 & Qstn 30 & Qstn 35 & Qstn 31 \\
\hline Qstn 29 & Qstn 29 32 \\
\hline Qstn 35 & Qstn 31 & Qstn 29 & Qstn 35 \\
\hline Qstn 31 & Qstn 35 & Qstn 32 & Qstn 28 \\
\hline Qstn 28 & Qstn 28 & Qstn 26 & Qstn 27 \\
\hline Qstn 27 & Qstn 27 & Qstn 28 & Qstn 26 \\
\hline
\end{tabular}

